\title{
Work Participation in Cultural Operations of Rice Farming by Tribal and Non-Tribal Labourers in Wayanad district : A Comparative Analysis
}

\author{
P.M. Vishnu Narayanan ${ }^{1}$ and A. Anilkumar ${ }^{2}$
}

\begin{abstract}
Rice is a traditional staple food crop of India, having high cultural and ecological significance in the present global scenario. Tribal labourers in Wayanad district of Kerala had been the traditional labourers in rice farming. The consequent migration of non-tribals to Wayanad district of Kerala had been changed the demographic and cultural entity of the district. The present study was conducted in Wayanad district to compare the work participation between tribal and non-tribal labourers. Twenty tribal and non-tribal labourers were selected from each selected panchayats and a total of one hundred and twenty respondents were included in the study. A well-structured interview schedule was used for collecting the data from the respondents. The data were tabulated and inferences were drawn after appropriate statistical analysis. The results show that majority of the tribal labourers had high work participation than non-tribals. While comparing based on gender, female labourers had high work participation than male labourers both in the case of tribal and non-tribal labourers.
\end{abstract}

Keywords : Rice farming, Work participation, Tribal labourers, Wayanad.

\section{INTRODUCTION}

Wayanad was traditionally one of the important rice growing districts of Kerala. Consequent to increase in population as a result of migration from north Malabar and central Travancore, cropping pattern in the district had changed in favour of cash crops and other plantations. Wayanad is the district having highest concentration of tribespeople in Kerala (GOI, 2011). These tribespeople were traditional labourers in rice farming since time immemorial.

Most of the rice farmers prefer tribal labourers to work in their fields, as they are experts in indigenous agricultural practices and possess rich experience in various aspects of cultivation. As population increased in the district due to migration, non-tribal

1-Meladath House, Valiparambu, Puthoor, Kottakkal, Malappur District, Kerala - 676503 and 2. Dean, Kerala Agricultural University, Vellayani - 695522 , Thiruvananthapuram, Kerala. 
people also stared working as labourers. Comparative analysis of tribal and nontribal labourers will help us to know the details of work participation in different operations of rice farming and other social dynamics.

\section{METHODOLOGY}

The study was carried out in the Wayanad district of Kerala state in India. Wayanad district was purposively selected for the study, since this district has the highest concentration of tribespeople. Mananthavady, Sulthan Bathery and Vythiri are the three taluks in Wayanad district. From each taluk, one panchayat having highest population was purposively selected for the study. From each selected panchayat one padashekharam with highest area was selected. From each selected padashekharam twenty tribal labourers and twenty non-tribal labourers were selected, at random. Thus, 120 respondents formed the sample of study. Data were collected using a pre-tested interview schedule and the statistical analysis used included in this study were percentage analysis and Krushkal - Wallis test. Work participation was studied on three dimensions viz., extent of participation in different operations of rice farming, work participation based on performance and work participation based on gender.

Table 1.

Extent of Work Participation in Different Operations of Rice Farming.

$(n=120)$

\begin{tabular}{|c|c|c|c|c|c|}
\hline \multirow[t]{2}{*}{ S1.No. } & \multirow[t]{2}{*}{ Operations } & \multicolumn{2}{|c|}{$\begin{array}{c}\text { Tribal labourers } \\
(n=60)\end{array}$} & \multicolumn{2}{|c|}{$\begin{array}{l}\text { Non-tribal labourers } \\
\qquad(\mathrm{n}=60)\end{array}$} \\
\hline & & No. & $\%$ & No. & $\%$ \\
\hline 1. & Land preparation & 56 & 93 & 54 & 90 \\
\hline 2. & Nursery management & 54 & 90 & 58 & 96 \\
\hline 3. & Transplantation & 42 & 70 & 24 & 40 \\
\hline 4. & $\begin{array}{l}\text { Intercultural } \\
\text { Operations }\end{array}$ & 49 & 81 & 48 & 80 \\
\hline 5. & Water management & 37 & 61 & 35 & 58 \\
\hline 6. & Harvesting & 55 & 91 & 48 & 80 \\
\hline 7. & $\begin{array}{l}\text { Postharvest } \\
\text { Management }\end{array}$ & 42 & 70 & 40 & 66 \\
\hline
\end{tabular}


Work Participation in Cultural Operations of Rice Farming by Tribal and Non-Tribal Labourers in Wayanad district :

A Comparative Analysis

\section{FINDINGS AND DISCUSSION}

From Table 1, it can be understood that the tribal labourers' participation in various operations of rice farming was higher, especially in land preparation (93 per cent), nursery management (90 per cent), transplantation (70 per cent)), intercultural operations (81 per cent), harvesting (91 per cent), and postharvest management (70 per cent).

On the other hand, the non-tribal labourers had a higher participation in operations such as land preparation $(90$ per cent), nursery management (96 per cent), intercultural operations (80 per cent), and harvesting (80 per cent).

Table 2.

Work Participation Based on Performance

$(\mathrm{n}=120)$

\begin{tabular}{|c|c|c|c|c|c|c|}
\hline \multirow[t]{2}{*}{$\begin{array}{l}\text { S1. } \\
\text { No. }\end{array}$} & \multirow[t]{2}{*}{ Category } & \multirow[t]{2}{*}{ Score Range } & \multicolumn{2}{|c|}{$\begin{array}{c}\text { Tribal } \\
\text { labourers } \\
(n=60)\end{array}$} & \multicolumn{2}{|c|}{$\begin{array}{c}\text { Non }- \text { Tribal } \\
\text { labourers }(n=60)\end{array}$} \\
\hline & & & No. & $\%$ & No. & $\%$ \\
\hline 1. & Low & 17 to 21 & 17 & 28 & 26 & 43 \\
\hline 2. & High & 21-35 & 43 & 72 & 34 & 57 \\
\hline 3. & \multicolumn{2}{|l|}{ Average score } & \multicolumn{2}{|c|}{$21.66(88.31)$} & \multicolumn{2}{|c|}{$21(74.9)$} \\
\hline
\end{tabular}

Kruskal Wallis $=14.956(\mathrm{p}=0.0006)$

$\mathrm{CD}(.05)$ for $60,60=18.989$

(CD- critical difference)

\section{Work participation based on performance}

A perusal of the table reveals that majority (72 per cent) of the tribal labourers had high work participation and only 28 per cent of them had low work participation. The non-tribal labourers showed similar kind of work participation.

Kruskal - Wallis test was done to analyse the significant difference between work participation based on performance by tribal and non-tribal labourers.

By comparing the average scores of work participation it can be seen that there is no significant difference between the average score of work participation based on performance between tribal and non-tribal labourers.

Tribal labourers showed a higher level of work participation compared to non-tribal labourers. This result was in line with the findings of Goswami et al. (2006).Tribal labourers were the traditional workers in the rice tracts of Wayanad. They were familiar with all the operations in rice farming. Therefore, it can be inferred that work participation 
was more among tribal population than the non-tribal population.

High preference of tribal labourers than non-tribal labourers by farmers, might be because of their rich experience in rice farming possessed by them and they are possibly less assertive in demanding higher wages.

Table3.

Work Participation Based on Gender

\begin{tabular}{|c|c|c|c|c|c|c|c|c|c|}
\hline \multirow{4}{*}{$\begin{array}{l}\text { S1. } \\
\text { No. }\end{array}$} & \multirow{4}{*}{ Operations } & \multicolumn{4}{|c|}{$\begin{array}{c}\text { Tribal labourers } \\
\qquad(n=60)\end{array}$} & \multicolumn{4}{|c|}{$\begin{array}{l}\text { Non-tribal labourers } \\
\qquad(\mathrm{n}=60)\end{array}$} \\
\hline & & \multirow{2}{*}{\multicolumn{2}{|c|}{$\begin{array}{c}\text { Male } \\
(n=30)\end{array}$}} & \multirow{2}{*}{\multicolumn{2}{|c|}{$\begin{array}{c}\text { Female } \\
(n=30)\end{array}$}} & & & \multirow{2}{*}{\multicolumn{2}{|c|}{ Female }} \\
\hline & & & & & & \multicolumn{2}{|c|}{$\begin{array}{c}\text { Male } \\
(\mathrm{n}=30)\end{array}$} & & \\
\hline & & No. & $\%$ & No. & $\%$ & No. & $\%$ & $(n=30)$ & $\%$ \\
\hline 1. & Land preparation & 30 & 100 & 26 & 86 & 29 & 97 & 25 & 83 \\
\hline 2. & $\begin{array}{l}\text { Nursery } \\
\text { management }\end{array}$ & 26 & 89 & 27 & 90 & 28 & 93 & 30 & 100 \\
\hline 3. & Transplantation & 12 & 40 & 30 & 100 & 9 & 30 & 15 & 50 \\
\hline 4. & $\begin{array}{l}\text { Intercultural } \\
\text { Operations }\end{array}$ & 22 & 73 & 27 & 90 & 22 & 73 & 26 & 87 \\
\hline 5. & $\begin{array}{l}\text { Water } \\
\text { management }\end{array}$ & 22 & 73 & 15 & 50 & 20 & 67 & 15 & 50 \\
\hline 6. & Harvesting & 27 & 90 & 28 & 93 & 20 & 67 & 28 & 93 \\
\hline 7. & $\begin{array}{l}\text { Postharvest } \\
\text { management }\end{array}$ & 18 & 60 & 24 & 80 & 15 & 50 & 25 & 83 \\
\hline
\end{tabular}

\section{Work Participation Based on Gender}

Upon scrutinizing Table 3 , it can be understood that land preparation (100 per cent), harvesting (90 per cent) and nursery management (89 per cent) are the important operations done by the male tribal labourers. Whereas transplantation (100 percent), harvesting (93 per cent), nursery management (90 per cent), intercultural operations (90 per cent), land preparation (86 per cent) and postharvest management (80 per cent) are the important operations carried out by the female tribal labourers. 
Work Participation in Cultural Operations of Rice Farming by Tribal and Non-Tribal Labourers in Wayanad district :

A Comparative Analysis

In case of non-tribal labourers, land preparation (97 per cent) and nursery management (93 per cent) are the important operations performed by male non-tribal labourers. Whereas land preparation (83 percent), nursery management (100 percent), intercultural operations (87 per cent), harvesting (93 per cent) and post harvest management (83 per cent) are the important operations done by the female non-tribal labourers.

From Table 3, it could be inferred that tribal labourers had higher work participation compared to non-tribal labourers, in the case of both male and female. The female labourers had more work participation compared to the male labourers. This result is in line with the findings of Kumar \& Nag (2004).

Tedious work like transplantation, intercultural operations etc., were carried out by the women labourers. Whereas the 'masculine' operations such as land preparation was handled by male labourers. Interestingly, in rice farming, women labourers are the least paid compared to male labourers.

\section{CONCLUSION}

From the study, it can be concluded that tribal labourers had high work participation compared to the nontribal labourers. Tribal and non-tribal labourers showed high participation in practices such as, land preparation and nursery management. Women labourers were subjected to do work with more drudgery like, transplanting, intercultural operations, harvesting etc., and women labourers showed higher work participation compared to male labourers. The extension professionals and policy makers should take note of the results of the study while formalating strategies to sustain rice production in the state.

\section{REFERENCES}

GOI. (2011). General Population Table, Kerala Part. Directorate of Census Operation, Census of India, Government of India, 2011

Goswami, M., Sharma, P.J., Mipun, B.S., \& Sarma, P.C. (2006). Women in Agriculture: A Case Study of Mishing Tribe. In: Deb, B.J. and Ray, B.D. (eds.), Changing Agricultural Sce nario in North-East India. Concept Publishing Company, New Delhi, pp. 301-312.

Kumar, P.N. \& Nag, A. (2004). Drudgery, Accidents and Injuries in Indian Agriculture. Retrieved from https://www.researchgate.net/ publication/8577770_Drudgery_ Accidents_and_Injuries_in_Indian_ Agriculture. 